Jurnal Psikologi Teori dan Terapan

2017, Vol.7, No. 2, 76-81, ISSN: 2087-1708

\title{
Perbedaan Efikasi Politik Ditinjau dari Tipe Kepribadian Introversi dan Ekstraversi Pada Dewan Perwakilan Mahasiswa
}

\author{
Andi Nurcahya, dan Olievia Prabandini Mulyana \\ Program Studi Psikologi Universitas Negeri Surabaya
}

\begin{abstract}
: some previous research show that there is a significant correlation between extraversion personality with political efficacy. The purpose of this study was to determine whether there are differences in political efficacy in individuals with different personality types other than extraversion, named introversion. Samples in this study were 42 college students of Universitas Negeri Surabaya who are members of Student Representative Council (Dewan Perwakilan Mahasiswa). A quantitative research methods with data collection technique using questionnaires is the method used for this study. The result of the independent sample t-test on the political efficacy variables reveals sig. (2-tailed) of 0,094, which means there is no significant difference in political efficacy variables in terms of introversion and extraversion personality type on Dewan Perwakilan Mahasiswa at Universitas Negeri Surabaya.
\end{abstract}

Key words: Political efficacy, personality, introversion, extraversion, college student.

\begin{abstract}
Abstrak: Berdasarkan penelitian sebelumnya menunjukkan adanya hubungan signifikan antara kepribadian ekstraversi dengan efikasi politik. Tujuan dari penelitian ini adalah untuk mengetahui apakah terdapat perbedaan efikasi politik pada individu dengan tipe kepribadian berbeda selain ekstraversi, yaitu introversi. Subjek dalam penelitian ini adalah 42 mahasiswa Universitas Negeri Surabaya yang tergabung dalam organisasi Dewan Perwakilan Mahasiswa. Merupakan metode penelitian kuantitatif dengan teknik pengumpulan data menggunakan kuesioner. Hasil dari uji-t independen sampel menunjukkan nilai sig. (2-tailed) sebesar 0,094 yang artinya tidak ada perbedaan signifikan variabel efikasi politik berdasarkan tipe kepribadian introversi dan ekstraversi pada Dewan Perwakilan Mahasiswa Universitas Negeri Surabaya.
\end{abstract}

Kata kunci: Efikasi politik, kepribadian, introversi, ekstraversi, mahasiswa.

Mahasiswa merupakan seseorang yang memperoleh pendidikan pada jenjang yang lebih tinggi (UUD No. 12 tentang pendi-dikan tinggi tahun 2012). Mahasiswa melakukan proses-proses pengembangan diri melalui kegiatan ekstrakulikuler. Menurut Kenniston (dalam Santrock, 2012), mahasiswa yang disebut juga sebagai kaum muda akan berjuang untuk membangun dirinya menjadi pribadi yang mandiri dan terlibat secara sosial. Pengembangan diri bisa dilakukan dengan cara bergabung ke dalam organisasi mahasiswa intra perguruan tinggi.

Menurut buku Panduan Mahasiswa Universitas Negeri Surabaya tahun 2015, DPM merupakan badan legislatif atau badan perundang-undangan mahasiswa di

Korespondensi tentang artikel ini dapat dialamatkan kepada Andi Nurcahya melalui email: andinurcahya@mhs.unesa.ac.id; atau ke Olievia P.Mulyana: olieviaprabandini@unesa.ac.id 
tingkat fakultas yang memiliki kewenangan untuk menjabarkan tata tertib (peraturan) yang telah disusun oleh Majelis Permusyawaratan Mahasiswa (MPM) sebagai pedoman kerja bagi Badan Eksekutif Mahasiswa (BEM) di tingkat fakultas dan Jurusan.

Keterlibatan mahasiswa di dalam DPM mengharuskannya untuk memiliki sikap yakin akan kemampuan yang dimiliki. Keyakinan bahwa satu orang bisa membuat sebuah perubahan terhadap keputusan politik (Sylvester, 2010), keyakinan bahwa seseorang dapat memberikan hasil yang diinginkan karena tindakannya (Gallego dan Oberski, 2011), perasaan bahwa tindakan atau partisisipasi politik individu dapat berpengaruh terhadap proses politik (Matulessy, 2013), disebut sebagai efikasi politik.

Efikasi politik terdiri dari dimensi efikasi politik eksternal dan efikasi politik internal (Schulz, 2005; Morrell, 2005; Kahne \& Westheimer, 2006; Curran, 2008; Sylvester, 2010; Louisa, et al., 2012; Ognyanova, 2012). Efikasi politik eksternal merupakan keyakinan bahwa sistem politik tanggap terhadap tuntutan politik, sedangkan efikasi politik internal merupakan keyakinan bahwa individu cukup kompeten untuk membuat perubahan dalam keputusan politik (Sylvester, 2010). Efikasi politik eksternal lebih dipengaruhi oleh interaksi individu dengan lingkungannya, sedangkan efikasi politik internal lebih dipengaruhi oleh persepsi yang dimiliki seseorang mengenai kemampuan dirinya.

Efikasi politik yang tinggi pada masyarakat selalu dilihat sebagai kebutuhan atas kestabilan demokrasi. Masyarakat yang secara pasti memiliki efikasi politik akan menjadi pendukung pada sistem demokrasi. Masyarakat harus merasa yakin bahwa mereka mempunyai kekuatan untuk mempengaruhi tindakan dari pemerintah (Schulz, 2005). Efikasi politik merupakan variabel penting dalam mempengaruhi keterlibatan seseorang di bidang politik
(Schulz, 2005; Vecchione \& Caprara, 2009; Abraham \& Viatrie, 2013; Matulessy, 2013).

Keterlibatan didalam organisasi bisa meningkatkan efikasi politik (Sylvester, 2010), karena efikasi politik meningkat seseorang akan lebih terlibat secara aktif dalam organisasi (Schulz, 2005; Vecchione \& Caprara, 2009; Abraham \& Viatrie, 2013; Matulessy, 2013). Wawancara pendahuluan menunjukkan bahwa sikap efikasi tidak selalu membuat seseorang terlibat secara aktif. Terdapat bermacam alasan atau faktor-faktor lain yang melatarbelakangi ketidakaktifan seorang anggota dalam organisasi. Ada hubungan partisipasi organisasi dengan tingkat efikasi politik yang dimiliki, namun ketidak aktifan tidak hanya disebabkan oleh efikasi politik. Efikasi politik anggota yang tidak aktif bisa saja sama dengan mereka yang aktif dalam organisasi.

Faktor lain yang berhubungan dengan efikasi politik adalah kepribadian. Menurut Jung (dalam Alwisol, 2012) kepribadian atau psyche merupakan mencakup keseluruhan fikiran, perasaan dan tingkahlaku, kesadaran dan ketidaksadaran.

Penelitian yang dilakukan oleh Vecchione \& Caprara (2009) menunjukkan adanya hubungan antara kepribadian seseorang terhadap partisipasi politik yang dilakukan, melalui mediasi efikasi politik. Hasil penelitian menunjukkan bahwa kepribadian ekstraversion dan openness memiliki tingkat efikasi politik yang tinggi.

Teori mengenai kepribadian ekstraversi pertama kali disebutkan oleh Jung (dalam Alwisol, 2012). Terdapat dua Aspek kepribadian yang beroperasi secara sadar dan tidak sadar, yaitu attitude dan function. Attitude terdiri dari introversi dan ekstraversi, sedangkan function terdiri dari thinking, feeling, sensing, dan intuiting. Menurut Jung (dalam Alwisol, 2012), setiap orang memiliki tipe introversi dan ekstraversi di dalam kepribadiaannya, hanya saja ada yang lebih dominan atau 
sadar dan ada yang tidak dominan atau tidak sadar.

Orang dengan introversi cenderung mengarahkan pribadinya kepada dunia subjektif, yaitu dunia di dalam dirinya. Orientasi utama tertuju ke dalam, pikiran, perasaan, dan tindakan dipengaruhi oleh faktor subjektif. Orang dengan ekstraversi cenderung mengarahkan pribadinya kepada dunia objektifnya, yaitu dunia di luar dirinya. Orientasi utama tertuju ke luar, pikiran, perasaan, dan tindakan dipengaruhi oleh lingkungan sekitarnya, baik sosial maupun non-sosial. (Suryabrata, 2012).

Ketika mahasiswa mencalonkan dirinya untuk menjadi anggota DPM, artinya mahasiswa tersebut sudah memiliki efikasi politik dalam dirinya, dan keterlibatan mahasiswa di dalam organisasi DPM bisa meningkatkan tingkat efikasi politik yang dimiliki. Namun ketidakaktifan anggota dalam organisasi DPM tidak selalu berpengaruh terhadap efikasi politik yang dimiliki. Salah satu faktor yang berpengaruh nelitian ini termasuk penelitian populasi tanpa sampel penelitian. Instrumen penelitian menggunakan skala efikasi politik dan alat ukur EPI. Skala efikasi politik berdasarkan skala penelitian yang dilakukan oleh Murphy, P. J. (2011). Alat ukur EPI digu-nakan untuk mengklasifikasi responden ke dalam tipe kepribadian Introversi dan Ekstraversi serta tingkat kejujuran jawaban dari responden. Analisis data menggu-nakan independent sample $t$ test dengan bantuan software IBM SPSS Statistics 21 for windows.

\section{Hasil}

Hasil independent sample t-test menunjukkan nilai sig. (2-tailed) sebesar 0,94. Nilai signifikansi lebih besar dari 0,05 maka hipotesis penelitian ditolak, yang artinya tidak terdapat perbedaan signifikan variabel efikasi politik berdasarkan tipe kepribadian Introversi dan ekstraversi pada anggota Dewan Perwakilan Mahasiswa Universitas Negeri Surabaya.

Tabel 1. Hasil Uji Statistik Deskriptif

\begin{tabular}{lllrrrr}
\hline Kepribadian & $\mathrm{N}$ & Mean & Std. Deviation & Std. Error & Min & Max \\
\hline Introversi & 20 & 84.3500 & 11.37067 & 2.54256 & 66 & 111 \\
Ekstraversi & 22 & 90.0909 & 10.35057 & 2.20675 & 72 & 114 \\
Total & 42 & 87.3571 & 11.10004 & 1.71277 & 66 & 114 \\
\hline
\end{tabular}

terhadap efikasi politik adalah kepribadian. Bagaimana tingkat efikasi politik yang dimiliki anggota DPM dengan tipe kepribadian berbeda. Berdasarkan uraian tersebut, maka penelitian ini kemudian dilakukan untuk mengetahui apakah terdapat perbedaan efikasi politik ditinjau dari tipe kepribadian introversi dan ekstraversi pada Dewan Perwakilan Mahasiswa UniversitasNegeri Surabaya

\section{Metode}

Penelitian ini termasuk kedalam penelitian kuantitatif komparatif. Subjek penelitian merupakan 42 Mahasiswa Universitas Negeri Surabaya yang tergabung dalam Dewan Perwakilan Mahasiswa. Pe-
Berdasarkan tabel hasil analisis deskriptif diketahui bahwa kelompok kepribadian introversi mempunyai jumlah sampel 20 ditunjukkan dari $\mathrm{N}=20$ dan kelompok kepribadian ekstraversi mempunyai jumlah sampel 22 ditunjukkan dari $\mathrm{N}=22$. Kemudian mean (rata-rata) nilai efikasi politik untuk kelompok kepribadian introversi yaitu 84,35 dan kelompok kepribadian ekstra-versi yaitu 90,09. Kemudian mempunyai nilai standar deviasi kuesioner efikasi politik untukkelompok kepribadian introversi sebesar 11,37 dan kelompok kepribadian ekstraversi sebesar 10,35. Berdasar-kan tabel analisis deskriptif juga diketahui bahwa kelompok subjek introversi memperoleh nilai efikasi politik 
terendah 66 dan nilai tertinggi 111, kelompok subjek ekstraversi memperoleh nilai efikasi politik terendah 72 dan nilai tertinggi 114.

\section{Pembahasan}

Hasil dari independent sample t-test pada variabel efikasi politik menyimpulkan bahwa tidak ada perbedaan signifikan variabel efikasi politik pada anggota DPM Unesa yang memiliki tipe kepribadian introversi dan ekstraversi. Hasil ini menunjukkan bahwa baik kelompok dengan tipe introversi maupun ekstraversi memiliki efikasi politik yang sama. Salah satu penyebab timbulnya efikasi politik adalah keikutsertaan seseorang dalam organisasi. Penelitian Sylvester (2010) menunjukkan bahwa keterlibatan didalam organisasi bisa meningkatkan efikasi politik. Hal ini berpengaruh baik kepada mereka yang memiliki kepribadian introversi maupun ekstra-versi. Begitu pula ketika mahasiswa mencalonkan dirinya untuk bergabung ke dalam organisasi, artinya mahasiswa tersebut sudah memiliki keyakinan akan kemampuannya (efikasi politik) dalam dirinya. Kalaupun ada anggota yang tidak aktif, hal itu bukan karena efikasi politik yang mereka miliki, namun ada faktor lain yang mempengaruhi ketidak aktifan tersebut.

Apabila melihat hasil analisis deskriptif menunjukkan nilai mean (ratarata) efikasi politik untuk kelompok kepribadian introversi sebesar 84,35 dan kelompok kepribadian ekstraversi sebesar 90,09. Kelompok kepribadian ekstraversi memiliki nilai rata-rata yang lebih tinggi dari kelompok kepribadian introversi. Menurut Jung (dalam Alwisol, 2012), seseorang dengan kepribadian ekstraversi akan lebih memusatkan perhatiannya pada pengalaman obyektif, daripada kepribadian introversi yang memusatkan perhatiannya pada pengalaman subyektif. Pengalaman mahasiswa ketika berada dalam organisasi DPM akan lebih berdampak pada mereka yang memiliki kepribadian ekstraversi. Jung juga mengatakan seorang ekstraversi lebih terpengaruh oleh dunia disekitarnya (dalam Alwisol, 2012). Bukan berarti mahasiswa dengan kepribadian introversi juga tidak terpengaruh. Seorang introversi juga mengamati dunia luar, tetapi melakukan secara selektif dan lebih memakai pandangan subjektif mereka sendiri (Jung, dalam Alwisol 2012). Mahasiswa dengan kepribadian introversi juga memaknai pengalaman mereka ketika berada dalam organisasi DPM, namun efikasi politik yang mereka miliki lebih dipengaruhi oleh pandangan subjektif mereka sendiri.

Apabila dilihat berdasarkan kategori jenjang (ordinal), kelompok introversi memiliki mean 84,35 dan kelompok ekstraversi memiliki mean 90,09. Kedua kelompok memiliki mean pada kategori jenjang yang sama $(80<X \leq 94)$ yaitu kategori efikasi politik tinggi. Artinya baik mereka yang memiliki kepribadian introversi ataupun kepribadian ekstraversi, ketika memiliki pengalaman berorganisasi akan berpengaruh pada efikasi politik yang dimiliki. Seperti yang dijelaskan sebelumnya, pengaruh tersebut akan lebih tinggi pada mereka yang memiliki kepribadian ekstraversi.

Apabila dikategorisasikan bukan jenjang (nominal), kelompok kepribadian introversi memiliki nilai $51,04 \%$ pada efikasi politik internal dan $48,96 \%$ pada efikasi politik eksternal. Sedangkan kelompok kepribadian ekstraversi memiliki nilai $50,4 \%$ pada efikasi politik internal dan $49,6 \%$ pada efikasi politik eksternal. Kedua kelompok sama-sama memiliki kecendrungan efikasi politik internal yang lebih tinggi. Efikasi politik internal mengacu pada keyakinan seseorang akan kemampuan sendiri dalam memahami proses politik (Curran, 2008; Sylvester, 2010). Seorang mahasiswa yang tergabung dalam organisasi DPM, akan belajar mengenai proses-proses politik yang terjadi, karena DPM sendiri merupakan lembaga legislatif yang memiliki tugas 
sebagai pengawas kegiatan badan eksekutif di tingkat fakultas sesuai dengan peraturan yang telah dibuat. Pengalaman mahasiswa dalam DPM lebih meningkatkan tingkat efikasi politik internal yang dimiliki.

Sedangkan efikasi politik eksternal mengacu kepada rasa percaya akan lembaga atau pelaku politik (Curran, 2008; Sylvester, 2010). Tingkat efikasi politik internal lebih tinggi dari eksternal, tidak berarti bahwa mereka tidak percaya pada lembaga politik. Persentase efikasi politik internal dan eksternal hampir mendekati $50 \%$ atau hampir seimbang. Artinya mereka juga percaya akan lembaga atau pelaku politik. Lembaga politik itu sendiri merupakan organisasi DPM, yang mana mereka tergabung di dalamnya. Kolaborasi antara lembaga DPM yang mereka percaya (efikasi politik eksternal) dan pengalaman yang mereka alami di DPM (efikasi politik eksternal), kedua hal ini menjadikan mahasiswa kepribadian introversi ataupun ekstraversi memiliki tingkat efikasi politik yang tinggi.

\section{Simpulan}

Hasil penelitian ini menunjukkan bahwa tidak ada perbedaan yang signifikan antara efikasi politik pada anggota Dewan Perwakilan Mahasiswa (DPM) dengan tipe kepribadian introversi dan ekstraversi. Kelompok kepribadian ekstraversi memiliki rata-rata nilai (mean) lebih tinggi dari kelompok kepribadian introversi. Sementara berdasarkan kategori jenjang, kedua kelompok subjek penelitian berada pada kategori efikasi politik yang tinggi. Berdasarkan kategorisasi nominal, kedua kelompok subjek penelitian memiliki kecenderungan nilai efikasi politik internal lebih tinggi daripada efikasi politik eksternal, tetapi jarak perbedaan kedua efikasi politik tersebut tidak berbeda jauh.

Mempertimbangkan hasil penelitian ini, disarankan pada penelitian selanjutnya agar menggunakan variabel-variabel lain yang memiliki pengaruh terhadap efikasi politik. Hal ini disebabkan kelompok yang memiliki tipe kepribadian introversi maupun ekstraversi ternyata memiliki efikasi politik yang sama.

Selain itu, penelitian selanjutnya juga diharapkan untuk menggunakan subjek penelitian yang lebih besar dan berasal dari latar belakang yang lebih heterogen, sehingga bisa memperbaiki kekurangan dari penelitian ini.

\section{Daftar Pustaka}

Abraham, J. \& Viatrie, D. I. (2013). Apakah Kreativitas dan Sikap terhadap Ilmu Ekonomi Meramalkan Partisipasi Politik Mahasiswa? Peran Mediasi Efikasi Politik pada Mahasiswa di Malang, Jawa Timur. Makara Seri Sosial Humaniora, 17 (2), 109-125.

Alwisol. (2012). Psikologi Kepribadian. Edisi Revisi. Cetakan ke 11. Malang: UMM Press.

Curran, M. D. (2008). Affective Intelligence, the Political Persuasion Process, and Outcome Intent: An
Experimental Test. Dissertation. Graduate College, University of Arizona. Tucson, Arizona, USA.

Gallego, A. \& Oberski, D. (2011). Personality and Political Participation: The Mediation Hypothesis. Political Behavior, 34 (3), 425-451.

Indonesia. (2012). Undang-Undang Republik Indonesia Nomor 12 Tentang Pendidikan Tinggi. Jakarta: Sekretariat Negara.

Kahne, J. \& Westheimer, J. (2006). The Limits of Political Efficacy: 
Educating Citizens for a Democratic Society. 289-296.

Louisa H., Fang W., Ling F., Chen Y., Xiao H., et al. (2012). Political Efficacy and the Use of Local and National News Media among Undecided Voters in a Swing State: A Study of General Population Voters and First-time College Student Voters. Media and Communications Faculty Publications, 7 (4), 204-222.

Matulessy, A. (2013). Political Efficacy, Political Trust dan Collective Self Esteem dengan Partisipasi dalam Gerakan Mahasiswa. Jurnal Penelitian Psikologi, 04(01), 84106.

Murphy, P. J. (2011). An Analysis of Political Efficacy Socialisation among Threshold Voters in the Republic of Ireland. PhD Thesis. Ireland: University College Cork.

Ognyanova, K. (2012). Political Efficacy on the Internet: A Media System Dependency Approach. (Online). (http://www.kateto.net), diunduh 27 Februari 2015).
Santrock, J. W. (2012). Life-Span Development: Perkembangan Masa Hidup. Edisi 13. Jilid II. Alih Bahasa: Benedictine Widyasinta. Jakarta: Erlangga.

Schulz, W. (2005). Political Efficacy and Expected Political Participation among Lower and Upper Secondary Students: A Comparative Analysis with Data from the IEA Civic Education Study. (Online). (http://iccs.acer.edu.au), diunduh 27 Februari 2015).

Suryabrata, S. (2012). Psikologi Kepribadian. Cetakan ke 19. Jakarta: PT Raja Grafindo Persada.

Sylvester, D. (2010). Service Learning as a Vehicle for Promoting Student Political Efficacy. Journal for Civic Commitment, 16 (1), 1-10.

Vecchione, M. \& Caprara, G. V. (2009). Personality Determinants of Political Participation: The Contribution of Traits and Self-efficacy Beliefs. Journal of Personality and Individual Differences. 46 (4), 487492 